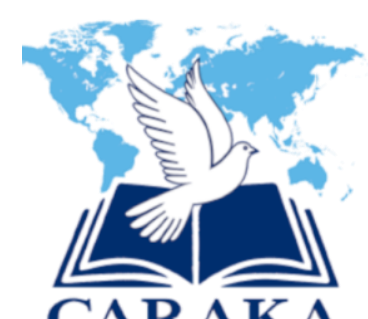

\title{
Peranan Membaca Alkitab Terhadap Kecerdasan Spiritual Anak Kristen
}

\author{
Marthen Mau, Saenom, Ferdiana Fransiska \\ Sekolah Tinggi Teologi Injili Arastamar (SETIA) Ngabang Kalimantan Barat \\ marthenluthermau@gmail.com \\ sainomjani@gmail.com \\ ferdianafransiska0504@gmail.com
}

\begin{abstract}
The role of reading the Bible is indispensable because the Bible has changed the lives of evil people, people are willing to die for the Bible, the Bible is God's most accurate book, the Bible contains messages of freedom that transform human lives, and connects readers with the person of Jesus Christ as a person. the most important thing in history, that can be trusted by mankind or Christian children so that their spirituality will grow well. This study aims to explain the role of reading the Bible on children's Christian spiritual intelligence. The research method used in this research is descriptive qualitative method, with the approach of observation and interview methods as primary sources; and documentation as a secondary source. The result of this research is that formal Christian educators actually have to play a proactive role in encouraging Christian children to be more faithful in reading the Bible because the essence of the Bible is able to grow their spiritual intelligence. So Christian children are increasingly motivated to read, listen to God's words, and be active in fellowship with Jesus Christ, so their spirituality will grow better.
\end{abstract}

Keywords: Role; Reading the Bible; intelligence; spirituality of children.

\begin{abstract}
Abstrak
Peranan membaca Alkitab sangat diperlukan karena Alkitab telah mengubah kehidupan manusia yang jahat, orang-orang bersedia mati untuk Alkitab, Alkitab merupakan buku Allah yang paling akurat, Alkitab berisi tentang pesan kebebasan yang mengubahkan hidup manusia, dan menghubungkan para pembaca dengan pribadi Yesus Kristus sebagai sosok terpenting di sepanjang sejarah, yang dapat dipercayai umat manusia atau anak-anak Kristen supaya spiritualitasnya bertumbuh baik. Penelitian ini bertujuan untuk menjelaskan peranan membaca Alkitab terhadap kecerdasan spiritual anak Kristen. Metode penelitian yang digunakan dalam penelitian ini adalah metode kualitatif deskriptif, dengan pendekatan metode observasi dan wawancara sebagai sumber primer; serta dokumentasi sebagai sumber sekunder. Hasil penelitian ini adalah sesungguhnya pendidik Kristen formal harus berperan proaktif untuk memberi semangat kepada anak-anak Kristen agar semakin setia dalam membaca Alkitab karena esensi dari Alkitab mampu menumbuhkan kecerdasan spiritualnya. Jadi anak-anak Kristen semakin diberikan motivasi untuk membaca, mendengarkan firman Tuhan, dan giat dalam persekutuan dengan Yesus Kristus, maka spiritualnya akan semakin bertumbuh baik.
\end{abstract}

Kata-Kata Kunci: Peranan; Membaca Alkitab; Kecerdasan; Spiritualitas Anak. 


\section{PENDAHULUAN}

Peranan membaca Alkitab sangat diperlukan karena mampu meningkatkan kecerdasan spiritual dan menangkal segala pengaruh buruk yang merusak hubungan yang baik dengan Kristus Yesus. Hal ini dapat diketahui bahwa sebuah laporan dari Religion in American Life mengisahkan bahwa para peneliti menemukan mereka yang sering membaca Alkitab, mempunyai kemungkinan $50 \%$ jauh lebih banyak untuk menolak obat-obatan yang terlarang daripada mereka yang tidak pernah membaca Alkitab. Di samping itu, mereka memiliki tingkat produktivitas yang lebih tinggi di atas rata-rata di tempat pekerjaan. Di penjara Lewes Remand di Inggris, seorang pendeta telah berhasil menjadikan sekitar 600 orang napi bertobat setelah mereka membaca Alkitab selama berbulan-bulan. Mereka memberikan kesaksian bahwa, "Alkitab itu ternyata lebih baik daripada mabuk." Jelas sekali, Alkitab memiliki pengaruh luar biasa bagi kehidupan manusia ${ }^{1}$ yang acapkali membaca Alkitab.

Sesungguhnya Alkitab memiliki manfaatnya jikalau dibaca oleh orang percaya. Ro, Woo Ho mengemukakan bahwa pada masa kini orang-orang Kristen memiliki Alkitab namun mereka kurang memiliki waktu untuk membacanya. ${ }^{2}$ Kalau pun mereka membaca sebagian orang Kristen termasuk anak-anak Kristen belum dapat mengerti konten Alkitab yang dibacanya. Ketika anak-anak Kristen membaca Alkitab lalu ditanya oleh orang lain; apakah kamu mengerti bagian Alkitab yang kamu baca? Pertanyaan semacam ini senada dengan ungkapan Ho bahwa bagaimanakah aku dapat mengerti kalau tidak ada yang membimbing aku $?^{3}$ Penulis mewawancarai Mikhael Yogi pada bulan April 2019 mengatakan bahwa dirinya kurang mengerti kalau membaca Alkitab pada bagian kitab-kitab tertentu. ${ }^{4}$ Penulis mengamati peserta didik Kristen di SMK Negeri 1 Parindu bahwa sebagian peserta didik Kristen kurang mengerti pada bagian kitab tertentu yang dibacanya tetapi penulis selalu mendorong mereka supaya tetap semangat dalam mempelajari firman-Nya.

Pada dasarnya semua tulisan di dalam Kitab Suci merupakan ilham dari Allah yang bermanfaat bagi umat manusia, sebagaimana di dalam 2 Timotius 3:16 tertulis, "Segala tulisan yang diilhamkan Allah memang bermanfaat untuk mengajar, untuk menyatakan kesalahan, untuk memperbaiki kelakuan dan untuk mendidik orang dalam kebenaran." Menurut Yunus Selan bahwa Alkitab merupakan Firman Allah yang diinspirasikan oleh Roh Kudus kepada manusia dengan menggunakan bahasa manusia supaya melaluinya setiap manusia dapat

\footnotetext{
${ }^{1} \mathrm{Https} / / /$ www.gkikayuputih.or.id/manfaat-membaca-alkitab/ diakses pada tanggal 2 November 2020.

${ }^{2}$ Ro, Woo Ho, Pembacaan Alkitab Secara Menyeluruh (Yogyakarta: Penerbit Andi, 2015), 3.

${ }^{3}$ Ibid.

${ }^{4}$ Mikhael Yogi, Wawancara (Pusat Damai: SMK Negeri 1 Parindu pada bulan April 2019).
} 
mengerti dan mengenal kehendak Tuhan sembari menerapkannya dalam tindakan praktisnya setiap hari. ${ }^{5}$

Membaca Alkitab merupakan pelajaran wajib bagi renungan harian orang Kristen. Sebab tanpa membaca Alkitab, kehidupan rohani Kristen akan kering dan berhenti untuk bertumbuh. Membaca Alkitab sangatlah penting karena Alkitab adalah Firman Tuhan. Oleh karena membaca Alkitab itu sangatlah penting, maka anak-anak Kristen harus dibimbing untuk membaca Alkitab secara benar dan bertanggung jawab.

Membaca Alkitab mampu meningkatkan kecerdasan spiritual. Kecerdasan adalah kecakapan seseorang atau setiap anak Kristen untuk mengatasi problematika yang dihadapinya secara bertubi-tubi. Munandir dalam Deslana R. Hapsarini \& Wahyu Suprihati bahwa kecerdasan adalah kemampuan seseorang untuk memecahkan masalah yang dihadapinya, terutama masalah yang menuntut kemampuan pikiran karena pikiran merupakan salah satu bagian tubuh manusia yang mudah dikendalikan oleh kuasa-kuasa lain apabila pikiran tidak di kontrol secara baik. ${ }^{6}$ Mimi Doe \& Marsha Walch dalam Hapsarini dan Wahyu mengulas bahwa spiritual adalah dasar bagi tumbuhnya harga diri, nilai-nilai, moral, dan rasa memiliki. Ia memberi arah dan arti bagi kehidupan kita tentang kepercayaan mengenai adanya kekuatan non fisik yang lebih besar dari pada kekuatan diri kita; suatu kesadaran yang menghubungkan kita langsung dengan Tuhan, atau apa pun yang kita namakan sebagai sumber keberadaan kita. ${ }^{7}$ Komunikasi yang intens dengan pribadi yang supranatural yakni Tuhan Yesus Kristus, maka spiritual akan bertumbuh dengan baik apalagi secara teratur mendengar Firman Tuhan (Rm. 10:17), membaca firman Tuhan (1 Tim. 4:13), melakukan firman Tuhan (Mat. 7:21), dan bersedia ikut menanggung penderitaan, penganiayaan, atau pencobaan (Mat. 5:10-13) pada puncak hidupnya beroleh kebahagiaan abadi. Bahkan unsur-unsur ini akan membentuk kepribadian setiap orang percaya termasuk anak-anak Kristen untuk menumbuhkembangkan spiritualitasnya.

Deslana R. Hapsarini \& Wahyu Suprihati berpendapat bahwa kecerdasan spiritual sang anak itu sangat penting, karena ia memiliki pendirian yang teguh dan tahu mana yang benar serta yang salah. Oleh karena itu, penting sekali bagi setiap orang bukan hanya meningkatkan atau mengembangkan kecerdasan intelektual (IQ) dan kecerdasan emosional

${ }^{5}$ Yunus Selan, “Alkitab Di Dunia Postmodern, ” Jurnal Luxnos Volume 5, Nomor 2 Edisi Juli-Desember 2019: 84-86.

${ }^{6}$ Deslana R. Hapsarini \& Wahyu Suprihati, "Peran Orang Tua Dalam Mengembangkan Kecerdasan Spiritual Anak Di Era Masa Kini," Veritas Lux Mea (Jurnal Teologi dan Pendidikan Kristen) Vol. 1, No. 2 (2019): 100.

${ }^{7}$ Ibid. 
(EQ) tetapi juga sangat penting untuk meningkatkan dan mengembangkan kecerdasan spiritualnya (SQ). ${ }^{8}$

Dalam kekristenan, kecerdasan spiritual harus berdasar pada Alkitab. Sikap hidup yang benar sebagai orang Kristen harus dibangun di atas dasar kebenaran Alkitab, baik itu pikiran, perilaku, dan tutur kata. Hapsarini \& Suprihati mendeskripsikan bahwa kecerdasan spiritual adalah kemampuan seseorang untuk menghadapi dan memecahkan masalah yang berhubungan dengan nilai, batin, dan kejiwaan. Kecerdasan ini terutama berkaitan dengan abstraksi pada suatu hal di luar kekuatan manusia yaitu kekuatan penggerak kehidupan dan semesta. ${ }^{9}$

Sesungguhnya pendidikan Kristen formal perlu memperkenalkan Tuhan Yesus Kristus melalui Kitab Suci Kristen sejak dini kepada anak-anak sangat diperioritaskan seperti Lois dan Eunike membimbing Timotius sejak masih kecil sehingga rohaninya bertumbuh dan mengenal keselamatan melalui iman kepada Kristus Yesus (2 Tim. 3:15). Dengan pertolongan Roh Kudus, anak-anak yang mencintai firman Tuhan sejak dini akan bertumbuh menjadi anak yang sehat secara spiritual. Dari pokok permasalahan yang dipaparkan sebelumnya, maka tujuan penelitian ini ialah untuk menjelaskan peranan membaca Alkitab terhadap kecerdasan spiritual anak-anak Kristen.

\section{METODE PENELITIAN}

Penelitian ini digunakan metode penelitian kualitatif deskriptif yang bertujuan mendeskripsikan peranan membaca Alkitab terhadap kecerdasan spiritual anak. Menurut Marthen Mau bahwa metode penelitian kualitatif adalah suatu pendekatan penelitian yang mengungkapkan situasi sosial tertentu dengan mendiskripsikan kenyataan secara benar, dibentuk oleh kata-kata berdasarkan teknik pengumpulan data dan analisis data yang relevan diperoleh dari situasi yang alamiah. ${ }^{10}$ Pendekatan kualitatif dilakukan untuk mengkaji kecerdasan spiritual anak-anak Kristen. Yuliana Margareta Tokuan, Wanto Rivaie, dan Imran menyatakan bahwa jenis deskriptif adalah suatu metode dalam meneliti status sekelompok manusia, suatu objek, suatu kondisi, suatu sistem pemikiran, ataupun suatu kelas peristiwa pada masa sekarang. ${ }^{11}$ Jenis deskriptif digunakan untuk menggambarkan kejadian yang nyata dalam sebuah hubungan fakta-fakta dengan menggunakan kata-kata rinci untuk merefleksikan data secara akurat dari sikap anak-anak Kristen.

\footnotetext{
${ }^{8}$ Ibid.

${ }^{9}$ Ibid.

${ }^{10}$ Marthen Mau, Implikasi Teologis Berita Pertobatan Yoel dalam Yoel 2:12-17; Magnum Opus: Jurnal Teologi dan Kepemimpinan Kristen, Vol 1, No 2 (Juni 2020):98.

11 Yuliana Margareta Tokuan, Wanto Rivaie, dan Imran, Artikel Penelitian: "Peran Guru Dalam Pembentukan Kepribadian Disiplin Siswa SMP Negeri 11 Kota Pontianak,” Program Studi Pendidikan Sosiologi Jurusan Pendidikan Ilmu-Ilmu Sosial Fakultas Keguruan dan Ilmu Pendidikan Universitas Tanjungpura Pontianak 2015.
}

94 | Copyright@ 2021, CARAKA, ISSN 2722-1407 (Cetak), 2722-1393 (Online) 
Penelitian dilakukan di SMK Negeri 1 Parindu Sanggau pada bulan Januari sampai bulan Juni 2019. Sumber penelitian ditetapkan dengan menggunakan teknik purposive, karena dipilih dengan pertimbangan dan kriteria tertentu, sehingga peneliti mendapatkan informasi dari sumber kriteria yang ditentukan oleh peneliti. Sumber data primer diperoleh secara langsung melalui observasi dan wawancara yang telah dilakukan antara peneliti dengan informan. Adapun sumber penelitian yaitu peserta didik Kristen di SMK Negeri 1 Parindu Sanggau. Sumber data Sekunder dalam penelitian berupa dokumentasi yakni buku, jurnal terakreditasi, artikel penelitian, dan internet. Alasan penulis memilih SMK Negeri 1 Parindu sebagai objek penelitian ialah: Pertama, secara geografis letak SMK Negeri 1 Parindu sangat strategis; kedua, jarak tempuh dari tempat tinggal ke lokasi penelitian ditempuh dengan waktu 12-20 menit; ketiga, penulis pertama sebagai pendidik agama Kristen honorer di SMK Negeri 1 Parindu.

Proses analisis data dilakukan secara induktif yang meliputi komponen reduksi data, display data, dan penarikan kesimpulan atau verifikasi data. Tahapan-tahapan penelitian yang dilakukan para penulis adalah: Pertama, para penulis mendesain pokok masalah dan menentukan judul penelitian pada bulan Januari 2019; kedua, memohon izin secara lisan kepada Kepala SMK Negeri 1 Parindu pada bulan Pebruari 2019; ketiga, para penulis mengumpulkan data primer yakni penelitian observasi dari (Maret 2019 - 2020), interview dari (April - September 2019), dan dokumen sekunder berupa buku-buku, jurnal terakreditasi, dan bahan dari internet; keempat, data yang diterima dari para informan melalui penelitian dapat dilakukan verifikasi, yang sesuai dengan indikator pembahasan dapat digunakan, sedangkan yang tidak sesuai dengan pembahasan dapat diabaikan; kelima, penulis melakukan penulisan artikel pada tahun 2020 .

\section{HASIL DAN PEMBAHASAN}

\section{Peranan Membaca Alkitab}

Peranan ialah suatu perbuatan atau tindakan yang diperankan oleh setiap orang, baik yang berhubungan dengan hak maupun kewajiban secara bertanggung jawab. Menurut Soekanto dalam Suciati Nurmala, Adelina Hasyim, dan Hermi Yanzi menyatakan bahwa peranan merupakan proses dinamis kedudukan. Apabila seseorang melaksanakan hak dan kewajibannya sesuai dengan kedudukannya, dia menjalankan suatu peranan. Perbedaan antara kedudukan dengan peranan adalah untuk kepentingan ilmu pengetahuan. Keduanya tidak dapat dipisah-pisahkan karena yang satu tergantung pada yang lain dan sebaliknya. ${ }^{12}$ Peranan anak-anak Kristen dalam membaca Alkitab sangat diperlukan karena Alkitab adalah firman

${ }^{12}$ Suciati Nurmala, Adelina Hasyim, dan Hermi Yanzi, "Peranan Guru Terhadap Perubahan Sikap Sosial Siswa, ” Fakultas Keguruan dan Ilmu Pendidikan Universitas Lampung 2017, 6. 
Allah yang mampu memberikan inspirasi dan menata kehidupannya supaya semakin bermakna di mata Tuhan dan menjadi berkat bagi orang lain.

Peranan membaca Alkitab merupakan suatu kewajiban yang dilakukan oleh anak-anak Kristen dalam membaca Alkitab supaya spiritualitasnya atau imannya dapat bertumbuh dengan baik. Hal ini sesuai dengan perintah Tuhan di dalam 2 Timotius 3:15-16 yang berbunyi demikian: Ingatlah juga bahwa dari kecil engkau sudah mengenal Kitab Suci yang dapat memberi hikmat kepadamu dan menuntun engkau kepada keselamatan oleh iman kepada Kristus Yesus. Segala tulisan yang diilhamkan Allah memang bermanfaat untuk mengajar, untuk menyatakan kesalahan, untuk memperbaiki kelakuan dan untuk mendidik orang dalam kebenaran. Alkitab ialah buku Allah yang mampu mengubahkan hidup manusia karena itu harus dibaca. Ho menyatakan bahwa Alkitab (firman Allah) harus dibaca dari awal sampai akhir supaya dapat mengerti kehendak Allah. ${ }^{13}$ Jadi membaca Alkitab harus dimulai dari Kitab Kejadian hingga Kitab Wahyu supaya dapat mengerti kehendak Tuhan secara tepat.

Berdasarkan pengamatan penulis dari bulan Januari sampai dengan Desember 2019 sebagian informan sudah memiliki kerinduan untuk membaca Alkitab, tetapi sebagian informan belum sama sekali. Para informan yang telah memiliki kerinduan untuk membaca Alkitab hal ini dapat ditampakkan saat jam pelajaran agama Kristen para informan membawa Alkitab dan disuruh untuk membaca Alkitab dengan penuh antusias yang tinggi. Sedangkan sebagian informan belum memiliki kesadaran untuk membaca Alkitab hal ini dapat terlihat pada saat jam pelajaran agama Kristen tidak membawa Alkitab sama sekali.

\section{Alasan Membaca Alkitab}

Membaca Alkitab tentu memiliki alasan yang sungguh mendasar karena tanpa ada alasan, maka biasanya orang-orang akan jenuh bahkan sama sekali tidak berkeinginan untuk membaca Alkitab. Menurut Ogi bahwa alasan membaca Alkitab ialah dapat memahami dan mengetahui segala karya Allah yang menakjubkan di dalam Kitab Suci. ${ }^{14}$ Daniel P. Buttafuoco menjelaskan bahwa ada lima alasan untuk membaca Alkitab. Menurutnya: Pertama, Alkitab telah mengubah dunia; kedua, orang-orang bersedia mati untuk Alkitab; ketiga, Alkitab merupakan buku kuno yang paling akurat; keempat, Alkitab berisi tentang pesan kebebasan yang mengubahkan hidup; kelima, Alkitab menghubungkan para pembaca dengan sosok yang paling penting sepanjang sejarah. ${ }^{15}$

${ }^{13}$ Ho, 15 .

${ }^{14}$ Ogi, Wawancara (Pusat Damai: SMK Negeri 1 Parindu pada bulan Mei 2019).

15 Daniel P. Buttafuoco, Lima Alasan mengapa Alkitab adalah buku yang paling penting di dunia: Temukan kekuatan Firman Allah," disediakan di https://id.ptl.org/alive/why scripture. php diakses pada tanggal 2 November 2020. 
Tindakan atau perbuatan yang dilakukan oleh manusia tentang baik atau jahat dapat ditemukan secara langsung melalui membaca Alkitab. Karena itu, saat membaca Alkitab Allah berbicara kepada umat manusia sehingga manusia dapat memahami karya Allah secara sempurna bahwa Allah yang mengubahkan hidup manusia di dunia ini dan Allah menuntun manusia untuk berjumpa secara pribadi dengan Yesus sebagai sosok terpenting yang telah dikorbankan oleh Allah Bapa di atas kayu salib demi keselamatan umat manusia (bdk. Yoh. $3: 16)$.

\section{Manfaat Membaca Alkitab}

Para pendidik Kristen memiliki animo yang besar untuk membentuk kecerdasan spiritual anak-anak Kristen, termasuk orang tua Kristen dan guru pendidikan agama Kristen. Pengamatan penulis di SMK Negeri 1 Parindu bahwa sebagian anak Kristen menganggap Alkitab itu tidak penting sehingga pada jam pelajaran agama Kristen tidak membawa Alkitab. Karena itu, penulis terus-menerus memberikan motivasi kepada peserta didik Kristen supaya setiap kali pelajaran agama harus membawa Alkitab. Sebab bagi penulis dasar untuk menumbuhkan kecerdasan spiritual anak Kristen tentu mengetahui esensi pengajaran secara baik dari membaca Alkitab. Membaca Alkitab merupakan cara yang sangat penting untuk mengetahui kehendak Tuhan yang telah tertulis di dalam Firman-Nya. Untuk membaca Alkitab dilakukan, baik di rumah secara pribadi, bersama anggota keluarga maupun di dalam persekutuan anak-anak sekolah Minggu, remaja, dan pemuda-pemudi bahkan termasuk membaca Alkitab di tempat ibadah pada hari Minggu.

Sesudah mengetahui, memahami, dan mengerti esensi dari Firman Tuhan yang telah dipelajari, maka dapat disharingkan atau diajarkan kepada anak-anak. Penulis mewawancarai Nika Samudera tentang manfaat membaca Alkitab menurutnya bahwa Alkitab sangat bermanfaat bagi semua orang termasuk diri saya karena itu saya harus membaca Alkitab agar bisa mengetahui dosa apa yang sudah pernah saya lakukan. ${ }^{16}$

Pendidikan anak dalam perspektif Kristen hendak membawa anak-anak kepada pengembangan moral dan karakter kristiani yang berbasis pada Firman Tuhan. Dengan demikian tujuan yang harus nyata dari pendidikan membawa anak-anak pada pengembangan dan pertumbuhan karakter yang sesuai dengan Firman Tuhan. Jelaslah bahwa tanpa pendidikan rohani di dalam rumah, maka sang anaklah yang akan terkena imbasnya. Perlu diingat bahwa anak-anak adalah generasi penerus jemaat Tuhan yang tujuan eksistensinya adalah untuk kemuliaan Allah dalam mengajarkan dan mempertahankan kebenaran dan beribadah kepada Allah di dalam roh dan kebenaran (bdk. Yoh. 4:24). Hal ini tidak akan dapat

${ }^{16}$ Nika Samudera, Wawancara (Pusat Damai: SMK Negeri 1 Parindu pada bulan Juni 2019). 97 | Copyright@ 2021, CARAKA, ISSN 2722-1407 (Cetak), 2722-1393 (Online) 
dilakukan bila para orang tua Kristen tidak melakukan peranannya sebagai guru rohani kepada anak-anak mereka di rumah.

Guru pendidikan agama Kristen mendapatkan perintah dari Tuhan melalui firman-Nya untuk membentuk kecerdasan spiritual anak-anak Kristen di lembaga pendidikan formal. Hartono menjelaskan ada beberapa hal yang dapat dilakukan oleh pendidik Kristen dalam membentuk anak-anak Kristen antara lain memperkenalkan firman Tuhan sejak dini, mengajarkan cara berdoa, membiasakan beribadah kepada Tuhan, memberikan teladan mengasihi dan mempraktikkan kasih. ${ }^{17}$

Di dalam Ibrani 4:12 menyatakan bahwa Firman Tuhan bagaikan pedang bermata dua yang sanggup mengubahkan hidup manusia apabila diajarkan secara baik. Karena itu, firman Tuhan harus menembus dan memengaruhi seluruh eksistensi kehidupan orang percaya, termasuk amak-anak. Karena Alkitab adalah disiplin ilmu yang multigenerasi dan intergenerasi. Hal ini lebih dari sekadar tradisi kuno umat Israel mula-mula. ${ }^{18}$ Jadi, pengajaran firman Tuhan bukanlah sebuah tradisi yang diajarkan dari generasi ke generasi tetapi satu sumber mutlak yang mampu menyelamatkan umat manusia, khususnya orang-orang yang sungguh-sungguh telah percaya kepada Yesus Kristus. Untuk itu anak-anak merupakan bagian dari orang percaya yang harus menyediakan hati seperti tanah subur untuk menerima benih firman Tuhan agar dapat bertumbuh subur.

Membaca Alkitab secara rutin dan teratur setiap hari membantu dalam membangun kecerdasan spiritualitas. Membaca Alkitab tidak harus berlama-lama, tetapi harus secara rutin. Membaca Alkitab dapat membantu anak-anak Kristen untuk mengerti dan ajarkanlah untuk mengenal kitab-kitab dalam Alkitab. ${ }^{19}$ Membaca Alkitab secara rutin dapat memberi manfaat bagi sang pembaca. Ryadi Pramana menjelaskan bahwa surat kabar Washington Times, 30 Juli 1996 menuliskan riset yang dilakukan oleh Prof. Dr. Jeffrey Leven dan Dr. David Larsen, bahwa apabila orang membaca Alkitab secara teratur, bukan saja baik bagi jiwanya, tetapi juga baik bagi tubuhnya. Mereka melakukan penelitian terhadap lebih dari 500 orang selama berbulan-bulan. Ditemukan bahwa dari mereka yang membaca Alkitab secara teratur: tingkat depresi lebih rendah, jarang yang kecanduan obat terlarang maupun alkohol, jarang terjadi perpecahan dalam perkawinan, dan tingkat kesehatannya jauh lebih baik. ${ }^{20}$ Manfaat membaca Alkitab menjadi vitamin bagi tubuh, jiwa, dan raga manusia.

17 Handreas Hartono, “Membentuk Karakter Kristen Pada Anak Keluarga Kristen,” Kurios: Jurnal Teologi dan Pendidikan Agama Kristen. Vol 2, No 1 (2014): 62

18 Warren S. Benson dan Mark H. Senter III, Pedoman Lengkap untuk Pelayanan Kaum Muda 2 (Bandung: YKH, 1999), 312.

${ }^{19} \mathrm{Http} / / / \mathrm{www}$. livingwatersweb.com/ manfaat-membaca-alkitab/diakses pada tanggal 2 November 2020.

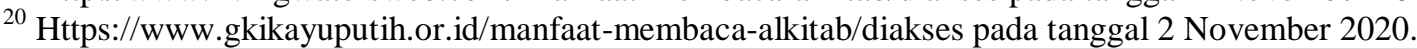


Seorang alumni SMK Negeri 1 Parindu saat diwawancarai oleh penulis dapat mengomentari bahwa persekutuan ibadah merupakan momen yang sangat penting untuk menumbuhkan pertumbuhan rohani karena di dalamnya anak-anak Kristen dapat membaca dan mendengarkan firman Tuhan yang disampaikan oleh guru agama Kristen demi kesehatan tubuh dan kesehatan jiwa. ${ }^{21}$ Menurut Sanyospwt bahwa manfaat membaca Alkitab ialah mempunyai tekanan darah lebih rendah, tingkat depresi lebih rendah, lebih sedikit penderita penyakit jantung, jarang yang kecanduan obat maupun alcohol, jarang terjadi perpecahan dalam perkawinan, tingkat kesehatannya jauh lebih baik. ${ }^{22}$

Anak-anak Kristen yang suka membaca Alkitab, maka tubuh akan lebih sehat karena esensi dari firman Tuhan mengatur kehidupan manusia untuk tidak menyalahgunakan tubuh yang Tuhan ciptakan secara sempurna dengan menikmati kebutuhan jasmani secara tidak bertanggung jawab. Pramana mengutarakan bahwa manfaat membaca Alkitab sebenarnya telah lama dikumandangkan seperti nasihat rasul Paulus kepada Timotius tentang pentingnya semua tulisan yang diilhamkan oleh Allah (bdk. 2 Tim. 3:16). Tulisan-tulisan itu bukan hanya membantu Timotius untuk mengajar, tetapi juga mendidik umat untuk menapak pada jalan Tuhan dan berbuat baik kepada sesama. Inilah sebabnya mengapa kita percaya bahwa Firman Tuhan bagai vitamin / obat yang manjur bagi tubuh, jiwa dan raga kita. ${ }^{23}$

Menurut Kartina Melly bahwa manfaat membaca Alkitab yakni: (1) Firman Tuhan menuntun kita menuju keselamatan sejati (2 Tim. 3:15; Mat. 4:4); (2) Firman Tuhan memberi kita ujian/cobaan kekuatan (1 Yoh. 2:14); (3) Firman Tuhan menegaskan keyakinan kita tentang keselamatan dan kehidupan kekal yang telah kita terima (1 Yoh. 5:13); (4) Firman Tuhan untuk memperkuat iman kita pada kekuatan doa (Yoh. 15:7); (5) Firman Tuhan membantu kita untuk menjadi semakin serupa dengan Allah (Yoh. 17:17; 15:3; Mzm. 119:9); (6) Firman Tuhan mampu menyukakan hati dan memberikan damai sejahtera (Mzm. 19:9; Yoh. 16:33); (7) Firman Tuhan mampu memberikan jalan keluar dan keberhasilan (Mzm. 119:105; Yos. 1:8). ${ }^{24}$

Dari paparan di atas, dapat disimpulkan bahwa manfaat membaca Alkitab setiap hari tidak hanya dirasakan dalam kehidupan rohani sang pembaca, tetapi juga dapat dilakukan dalam kehidupan sehari-hari. Hal yang penting untuk diingat adalah tidak cukup untuk sekadar membaca Alkitab. Diharapkan perlu sungguh-sungguh merenungkannya dan juga melakukannya dalam kehidupan sehari-hari. Mintalah tuntunan dan bimbingan dari Roh

${ }^{21}$ Lambok, Wawancara (Pusat Damai: SMK Negeri 1 Parindu pada bulan September 2019).

${ }^{22}$ Sanyospwt, "Manfaat Membaca Kitab Suci secara Teratur," pada 14 September 2018 disediakan di https://sanyospwt.com/2018/09/14/manfaat-membaca-kitab-suci-secara-teratur/ diakses pada tanggal 2 November 2020 .

${ }^{23} \mathrm{Https}$ ///www.gkikayuputih.or.id/manfaat-membaca-alkitab/ diakses pada tanggal 2 November 2020

24 Kartina Melly, Manfaat dan Keuntungan Membaca Alkitab, disediakan di Copyright 2020 livingwatersweb.com. Diakses pada tanggal 2 Nopember 2020. 
Kudus untuk selalu membimbing agar mendapatkan manfaat membaca Alkitab dalam kehidupan setiap hari.

\section{Kecerdasan Spiritual Anak}

Secara terminologi, kecerdasan diartikan sebagai kemampuan individu dalam memahami suatu fenomena secara kritis dan analitis dan menyelesaikan suatu masalah secara tepat dan efektif, sehingga mampu menyesuaikan diri dalam berbagai situasi lingkungan. J.P.Chaplin mendefinisikan kecerdasan dalam tiga definisi. Pertama, kemampuan menghadapi dan menyesuaikan diri terhadap situasi baru secara cepat dan efektif. Kedua, kemampuan menggunakan konsep-konsep abstrak secara efektif yang meliputi empat unsur: memahami, berpendapat, mengontrol, dan mengritik. Ketiga, kemampuan memahami pertalian-pertalian dan belajar cepat sekali. ${ }^{25}$ Jadi, kecerdasan seseorang dapat dilihat dari kemampuannya dalam memahami konsep-konsep pengetahuan, kemampuannya mengaplikasikan konsep pengetahuan dalam pemecahan suatu persoalan, dan kemampuannya menyesuaikan diri dalam berbagai situasi.

Dalam pengajaran iman Kristen bahwa pada saat Allah menciptakan manusia pada hari yang keenam dengan tujuan utama ialah supaya manusia dapat memuliakan nama Tuhan karena Tuhan sebagai Pribadi terpenting yang memberikan spiritualitas kepada umat yang bersekutu kepada-Nya. Oktoviana berpendapat bahwa anak-anak merupakan ciptaan Tuhan yang mulia karena itu perlu memuliakan Tuhan sebagai Penciptanya. Agar anak-anak Kristen dapat setia memuliakan Tuhan, maka pendidik Kristen perlu memberi petunjuk yang tepat sesuai dengan isi firman Tuhan. ${ }^{26}$ Memperkenalkan Tuhan kepada anak-anak Kristen sebagai sang Penciptanya supaya dapat percaya dan beriman kepada-Nya demi pertumbuhan spiritual.

Pengamatan penulis selama ini sebagian anak Kristen di SMK Negeri 1 Parindu Sanggau belum memiliki spirit yang matang karena itu guru pendidikan agama Kristen berperan memberikan dorongan kepada mereka untuk membaca Alkitab dan giat dalam mengikuti persekutuan dengan Tuhan supaya rohaninya semakin bertumbuh baik. ${ }^{27}$ Sebab tanpa membaca Alkitab dan giat dalam persekutuan ibadah dengan Tuhan Yesus Kristus, maka rohani tidak akan bertumbuh. Filadelfia saat diwawancarai penulis menurutnya bahwa anakanak Kristen tidak hanya cukup dibimbing oleh orang tua di rumah tetapi guru pendidikan agama Kristen juga harus mendidik, mengajar, dan membimbingnya supaya spiritualitas

25 J.P.Chaplin, Kamus Lengkap Psikologi (Jakarta: Raja Grafindo Persada, 1999), 253.

${ }^{26}$ Oktoviana, Wawancara (Pusat Damai: SMK Negeri 1 Parindu pada bulan Agustus 2019).

${ }^{27}$ Tim Penulis, Observasi terhadap Anak-anak Kristen (Pusat Damai: SMK Negeri 1 Parindu pada bulan Januari 2019-awal Januari 2020). 
semakin bertumbuh baik. ${ }^{28}$ Mutak dalam disertasinya mengatakan bahwa ada peningkatan dan pembaruan baru tentang spiritualitas dan pembinaan rohani di kalangan Kristen hari ini. Hal itu dikarenakan spiritualitas merupakan bagian integral dari setiap orang percaya. ${ }^{29}$ McGrath pada bagian lain meyakini bahwa spiritualitas itu sudah diterima dan dimengerti secara luas sebagai praktik-praktik iman. Lebih lanjut dikatakan bahwa spiritualitas itu sebagai sebuah pencarian terhadap pemenuhan pengalaman hidup kekristenan yang melibatkan seluruh pengalaman hidup seseorang dalam ruang lingkup di mana ia berada. ${ }^{30}$ Karena itu spiritualitas harus dimengerti sebagai keseluruhan yang melibatkan seluruh eksistensi.

Spiritualitas adalah sikap batin yang berjuang untuk menghayati iman sesuai dengan Firman Allah yang hidup. Ini tidak lain dari mengikuti Yesus Kristus dalam kehidupan seharihari dan menghayati kabar damai sejahtera di tengah dunia ini. ${ }^{31}$ Jadi spiritualitas yang benar adalah spiritualitas yang menekankan pada pembangunan relasi personal yang intim antara anak-anak Kristen dengan Tuhan, serta memiliki konsep teologi yang valid serta menjalankan tanggung jawab sosialnya dalam konteks masyarakat di mana ia menjadi garam dan terang dunia (bdk. Mat. 5:13-14). Dalam menghadapi segala macam tantangan, krisis, dan kesulitan hidup anak-anak Kristen harus dapat mengembangkan spiritualitasnya.

Jadi, spiritualitas menurut firman Tuhan adalah keberadaan setiap anak Kristen mengetahui cara yang seharusnya untuk berelasi dengan Tuhan, sesama, dirinya sendiri dan ciptaan lain apabila dilihat dari perkembangan modern saat ini. Pengetahuan yang dimiliki setiap anak Kristen tidak bersumber dari pola pikir manusia pada umumnya tetapi harus bersumber dari pola pikir Allah yang telah dinyatakan melalui Kitab Suci. Allah sebagai Pencipta alam semesta tentu mengetahui eksistensi segala ciptaan-Nya harus menjalani kehidupannya masing-masing.

Berdasarkan pemahaman pengertian tentang spiritual atau spiritualitas di atas dapat dikonklusikan bahwa spiritual atau spiritualitas adalah relasi, pengalaman, dan pengamalan iman kepercayaan ${ }^{32}$ anak-anak kepada Tuhan di dalam kehidupan sehari-hari. Pada sisi yang lain, pernyataan spiritualitas sebenarnya adalah roh setiap orang yang percaya yang bisa diartikan sebagai energi kehidupan yang membuat setiap orang untuk hidup, bernapas dan bergerak, serta spiritualitas juga berarti segala sesuatu di dalam tubuh manusia, yakni melalui pikiran, perasaan, tindakan dan karakter yang ditampilkannya.

\footnotetext{
${ }^{28}$ Filadelfia, Wawancara (Pusat Damai: SMK Negeri 1 Parindu pada bulan September 2019).

${ }^{29}$ A. Areng Mutak. The Importance of Spiritual Formation in Equipping Evangelical Seminary Students in Malang Region Indonesia. Ed.D. Dissertation. Asia Graduate School of Theology, (Philippines: 2008), 43.

${ }^{30}$ McGrath. E. Alister, Christian Spirituality: An Introduction. (Oxford: Blackwell Publishing, 2003), 2.

${ }^{31}$ E. G. Singgih, Apa Itu Teologi: Pengantar Ke dalam Ilmu Teologi (Jakarta; BPK Gunung Mulia, 2007), 29.

${ }^{32}$ Marthen Mau, Integritas Guru Pendidikan Agama Kristen Dalam Membimbing Kepribadian Peserta Didik, (Jakarta: PT Views, 2016), 65.
} 
Menurut Donah Zohar dan Ian Marshal (suami-isteri) pada awal tahun 2000 menyatakan bahwa kecerdasan spiritual dapat menjadi sumber motivasi yang memiliki kekuatan maha dahsyat, dan merupakan landasan yang diperlukan untuk memfungsikan intelligence quotient (IQ) dan emotional intelligence (EI) secara efektif bahkan merupakan kecerdasan tertinggi manusia. ${ }^{33}$ Dengan lain perkataan yang seirama dalam skripsi Ulfa Dwiyanti mengutarakan bahwa kecerdasan spiritual merupakan bentuk kecerdasan tertinggi yang memadukan antara kecerdasan intelektual dan kecerdasan emosional.

Kecerdasan spiritual dinilai sebagai kecerdasan yang tertinggi karena erat kaitannya dengan kesadaran seseorang bisa memaknai segala sesuatu dan merupakan jalan untuk bisa merasakan sebuah kebahagiaan. ${ }^{34}$ Kebahagiaan setiap orang termasuk anak-anak Kristen hanya akan menemukan puncak kebahagiaan terletak pada peningkatan spiritualitas melalui pembentukan yang acapkali dilaksanakan oleh pendidik informal (orang tua) dan formal (guru agama Kristen). Jadi kebahagiaan itu dapat ditemukan di dalam Tuhan yang memberikan mandat kepada para pendidik untuk membentuk kecerdasan spiritual anak-anak. Sebagaimana Wilcox dalam Nur Hotimah dan Yanto menyatakan bahwa kecerdasan spiritual merupakan kepercayaan terhadap kekuatan yang bersifat ketuhanan dan merupakan jalan hidup manusia agar mampu merasakan cinta dan kepercayaan terhadap Tuhan. ${ }^{35}$ Cinta kasih dan kepercayaan yang tulus kepada Kristus Yesus menjadi jalan satu-satunya untuk setiap orang percaya termasuk anak-anak Kristen menerima kecerdasan spiritual yang sempurna.

Menurut Ary Ginanjar Agustian bahwa spiritual question (SQ) adalah landasan yang diperlukan untuk memfungsikan intelligence quotient (IQ) dan EQ secara efektif. Spiritual Question (SQ) merupakan kecerdasan tertinggi manusia. Dalam emotional spiritual question (ESQ), kecerdasan spiritual adalah kemampuan untuk memberi makna spiritual terhadap pemikiran, perilaku dan kegiatan, serta mampu menyinergikan intelligence quotient (IQ), emotional question (EQ) dan spiritual question (SQ) secara komprehensif dan transendental. ${ }^{36}$ Hal senada diutarakan oleh Santy Sahartian bahwa kecerdasan spiritual adalah kemampuan untuk memberikan makna spiritual terhadap pemikiran, perilaku, dan kegiatan serta mampu menyinergikan IQ, EQ dan SQ dengan komperhensif. Oleh sebab itu, setiap individu perlu

33 Rifda El Fiah, "Mengembangkan Potensi Kecerdasan Spiritual Anak Usia Dini Implikasi Bimbingannya,” Konseli: Jurnal Bimbingan dan Konseling. Volume 01 No 2, 2014: 88.

34 Ulfa Dwiyanti, Skripsi: Pembentukan Kecerdasan Spiritual Melalui Kegiatan Ekstrakurikuler Keagamaan di SMK Negeri 4 Wajo Kab Wajo," (Makassar: UIN Makassar, 2018), 15.

${ }^{35}$ Nur Hotimah dan Yanto, "Peran Orang Tua Dalam Meningkatkan Kecerdasan Spiritual Anak Usia Dini, ” Indonesia Journal of Learning Education and Counseling; Vol 1, No 2, 2019, 85-93.

${ }^{36}$ Ary Ginanjar Agustian, Rahasia Sukses Membangun Kecerdasan Emosi dan Spiritual (Jakarta: Arga, 2001), 14. 
mengembangkan dan meningkatkan kecerdasan spiritual sebagai salah satu kecakapan hidup yang harus dimiliki. ${ }^{37}$

Kecerdasan spiritual merupakan salah satu kecerdasan yang sangat fundamental sebab kecerdasan intelektual saja tidak cukup untuk membuat seseorang berhasil dalam hidupnya. Yuliyatun berpendapat bahwa ada kecerdasan lain yang lebih menentukan keberhasilan dan kemampuan seseorang dalam mengadaptasikan diri dengan lingkungannya, yakni kecerdasan emosional. ${ }^{38}$ Goleman menguraikan bahwa kecerdasan intelektual tidak menjamin seseorang sukses hidupnya ketika kondisi emosionalnya yang tidak stabil. ${ }^{39}$ Meskipun memiliki nilai intelligence quotient (IQ) yang tinggi, namun ketika pengendalian diri dalam penggunaan emosi rendah, seringkali membuat seseorang gagal dalam hidupnya, misalnya seorang jenius tetapi melakukan kejahatan atau menjadi pecandu minuman keras, maka kejeniusannya menjadi sampah bagi masyarakat umum.

Jadi pada prinsipnya bahwa kecerdasan anak-anak Kristen dapat dilihat dari kemampuannya dalam memahami konsep-konsep pengetahuan tentang kebenaran Tuhan melalui membaca Alkitab secara teratur, sehingga berkemampuan untuk mengimplementasikan konsep pengetahuan dalam pemecahan suatu persoalan, dan kemampuannya menyesuaikan diri dalam berbagai situasi yang terjadi di sekitarnya.

Kecerdasan spiritual (SQ) yang berkembang baik akan ditandai dengan kemampuan seseorang untuk bersikap fleksibel dan mudah menyesuaikan diri dengan lingkungan, memiliki tingkat kesadaran yang tinggi, mampu menghadapi penderitaan dan rasa sakit, mampu mengambil pelajaran yang berharga dari suatu kegagalan, mampu mewujudkan hidup sesuai dengan visi dan misi, mampu melihat keterkaitan antara berbagai hal, mandiri, serta pada akhirnya membuat seseorang mengerti akan makna hidupnya.

Untuk membentuk kecerdasan spiritual (SQ) pada anak-anak tentunya harus dilakukan sejak dini atau pada saat anak-anak tersebut masih kecil. Hal tersebut bertujuan agar anakanak bisa menjadi orang yang memiliki kepekaan terhadap dirinya sendiri dan mengalami batin dan jiwa yang sejahtera. Kecerdasan spiritual amatlah penting dalam diri anak-anak, maka upaya pembentukan kecerdasan spiritual harus dimulai sejak dini pada anak-anak, yang dimulai di dalam lembaga pendidikan informal sebab lembaga pendidikan informal merupakan tempat yang berpengaruh positif pada perkembangan kecerdasan spiritual anak.

37 Santy Sahartian, "Pemahaman Guru Pendidikan Agama Kristen Tentang II Timotius 3:10 Terhadap Peningkatan Kecerdasan Spiritual Anak Didik, ” Jurnal Fidei, Vol.1, No. 2, 2018:163.

${ }_{38}$ Yuliyatun, “Mengembangkan Kecerdasan Spiritual Anak Melalui Pendidikan Agama,” Tulfula: Jurnal Inovasi Pendidikan Guru Raudhatul Athfal. Volume 1, Nomor 1, Juli-Desember 2013:153. 37.

${ }^{39}$ Daniel Goleman, Kecerdasan Emosional, terj. T. Hermaya. (Jakarta: Pustaka Gramedia Utama, 2007), 
Pada hakikatnya bahwa bukan semata-mata kecerdasan emosional dan intelektual yang dinilai penting untuk kesejahteraan manusia, melainkan kecerdasan spiritual sangat memengaruhinya. Kecerdasan spiritual adalah jenis kecerdasan yang erat kaitannya dengan kemampuan spiritual yang membantu seseorang untuk hidup lebih baik. Memiliki kemampuan ini memungkinkan untuk menyatukan spiritualitas, kehidupan batin dan kehidupan di luar dirinya.

Spiritualitas adalah pengalaman yang pribadi bagi tiap orang. Cara seseorang untuk menggapai kecerdasan spiritual juga berbeda-beda, ada yang melakukannya dengan yoga, meditasi, berdoa, dan sebagainya. Untuk melatih kesadaran bahwa memang tidak sempurna sebagai manusia. Ada kesalahan dan ego di dalam diri. Tetapi bukan berarti itu bisa membiarkan hal-hal ini menguasai. Oleh sebab itu, jika hal-hal buruk yang membuat jiwa tidak tenang dan terbiasa untuk hidup secara sadar dan mudah untuk menghargai serta menikmati hidup dengan baik.

Melatih kecerdasan spiritual tidak hanya menambah nilai bagi pertumbuhan pribadi. Pengalaman hidup juga bisa semakin kaya. Inteligensi spiritual dapat membuat diri lebih damai, puas dengan hidup, dan lebih mampu menghadapi kesulitan. Meluangkan waktu guna melihat ke dalam serta mengenal diri sendiri sehingga bisa mendapatkan ketenangan batin. Seorang pakar spiritualitas mendefinisikan kecerdasan spiritual sebagai kemampuan menggunakan spiritualisme untuk mencapai tujuan dan memecahkan suatu masalah. Menurutnya, kecerdasan spiritual terdiri dari empat kemampuan yakni Memiliki kesadaran diri yang baik, mampu mengambil manfaat dan makna dari pengalaman sehari-hari, mampu memanfaatkan sumber daya spiritual untuk memecahkan masalah, berbudi luhur. ${ }^{40}$

Untuk semakin meningkatkan pertumbuhan kecerdasan spiritual peserta didik Kristen, maka guru pendidikan agama Kristen perlu mendorong secara terus-menerus untuk giat dalam membaca firman Tuhan. Karena itu, jumlah pasal, ayat, dan kata dalam Alkitab yang harus dibaca orang percaya atau peserta didik Kristen SMK Negeri 1 Parindu sebagaimana tercantum pada tabel di bawah ini.

Tabel 1

Jumlah pasal, ayat, dan kata dalam Alkitab Perjanjian Lama dan Perjanjian Baru

\begin{tabular}{|c|c|r|r|l|}
\hline \multirow{2}{*}{ No. } & \multirow{2}{*}{ Nama Alkitab } & \multicolumn{3}{|c|}{ Jumlah } \\
\cline { 3 - 5 } & & \multicolumn{1}{|c|}{ Pasal } & \multicolumn{1}{c|}{ Ayat } & \multicolumn{1}{l|}{ Kata } \\
\hline 1. & Perjanjian Lama & 929 & 23.213 & 521.426 \\
\hline 2. & Perjanjian Baru & 260 & 7.958 & 170.292 \\
\hline \multicolumn{2}{|c|}{ Jumlah } & $\mathbf{1 . 1 8 9}$ & $\mathbf{3 1 . 1 7 1}$ & $\mathbf{6 9 1 . 7 1 8}$ \\
\hline
\end{tabular}

${ }^{40} \mathrm{Https}$ //personalitynabilah.wordpress. com/karakteristik-kecerdasan-spiritual/ diakses pada tanggal 2 November 2020. 
Setiap orang percaya atau peserta didik Kristen untuk menyelesaikan membaca Alkitab secara keseluruhan, maka waktu yang harus digunakan untuk membaca Alkitab sebagaimana pada tabel di bawah ini.

Tabel 2

Penggunaan waktu untuk membaca Alkitab

\begin{tabular}{|c|c|c|}
\hline No. & Waktu Membaca Alkitab & Cara Perhitungan \\
\hline 1. & $\begin{array}{l}\text { Membaca Alkitab untuk diselesaikan dalam } \\
\text { waktu } 1 \text { tahun. }\end{array}$ & $\begin{array}{l}\text { a. } 1.189 \text { pasal dibagi } 365 \text { hari, maka } 3 \\
\text { atau } 4 \text { pasal dibaca perhari. } \\
\text { b. } 31.171 \text { ayat dibagi } 365 \text { hari, maka } 85 \\
\text { atau } 86 \text { ayat dibaca perhari. } \\
\text { c. } 691.718 \text { kata dibagi } 365 \text { hari, maka } \\
1.895 / 1.896 \text { kata dibaca per hari. }\end{array}$ \\
\hline 2. & $\begin{array}{l}\text { Membaca Alkitab untuk diselesaikan dalam } \\
\text { waktu } 6 \text { bulan. }\end{array}$ & $\begin{array}{l}\text { a. } 1.189 \text { pasal dibagi } 183 \text { hari, maka } 7 \\
\text { pasal dibaca perhari. } \\
\text { b. } 31.171 \text { ayat dibagi } 183 \text { hari, maka } \\
171 \text { ayat dibaca per hari. } \\
\text { c. } 691.718 \text { kata dibagi } 183 \text { hari, maka } \\
3.780 \text { kata dibaca per hari. }\end{array}$ \\
\hline 3. & $\begin{array}{l}\text { Membaca Alkitab untuk diselesaikan dalam } \\
\text { waktu } 3 \text { bulan. }\end{array}$ & $\begin{array}{l}\text { a. } 1.189 \text { pasal dibagi } 92 \text { hari, maka } 12 \\
\text { atau } 13 \text { pasal dibaca per hari. } \\
\text { b. } 31.171 \text { ayat dibagi } 92 \text { hari, maka } 339 \\
\text { ayat dibaca per hari. } \\
\text { c. } 691.718 \text { kata dibagi } 92 \text { hari, maka } \\
7.519 \text { kata dibaca per hari. }\end{array}$ \\
\hline
\end{tabular}

\section{KESIMPULAN}

Berdasarkan hasil temuan penelitian ini bahwa peranan membaca Alkitab sangat diperlukan oleh karena kecerdasan spiritual anak-anak Kristen bermuara pada pengenalan, pemahaman, dan pengertian yang benar mengenai konten firman Tuhan yang dibacanya. Karena itu, pendidik Kristen informal dan formal harus memberikan motivasi secara terusmenerus kepada anak-anak Kristen untuk membaca Alkitab. Pendidik agama Kristen di Sekolah Menengah Kejuruan Negeri 1 Parindu karena proaktif dalam memberikan motivasi kepada peserta didik Kristen untuk membaca Alkitab, sehingga sebagian besar anak Kristen telah semangat dalam membaca Alkitab dan giat dalam mengikuti persekutuan ibadah di dalam Yesus Kristus pada setiap hari Minggu/setiap kesempatan. Penulis bisa mengetahui bahwa peserta didik Kristen di SMK Negeri 1 Parindu memiliki kecerdasan spiritualnya melalui membaca Alkitab dapat terlihat dengan baik karena ada perubahan hidup, baik dari pertumbuhan rohaninya, moralnya, emosionalnya, sosialnya, karakternya, sikapnya, tingkah lakunya, dan gaya dalam komunikasinya. 
Perkembangan sejauh ini anak-anak Kristen di SMK Negeri 1 Parindu melalui membaca Alkitab, sehingga sudah mampu membedakan antara hal yang benar dan yang jahat. Oleh karena mereka sudah mengetahui secara pasti bahwa Alkitab bermanfaat untuk mengajar, untuk menyatakan kesalahan, untuk memperbaiki kelakuan dan untuk mendidik orang dalam kebenaran. Sebab tanpa membaca Alkitab anak-anak Kristen tidak akan pernah mengetahui, memahami, mengerti, dan mengenal sang Penciptanya dan karya-Nya secara benar. Karena itu, anak-anak Kristen semakin setia dalam membaca Alkitab dan setia melakukan firman-Nya secara baik, sehingga tubuh, jiwa, dan rohnya akan semakin sehat di dalam Kristus Yesus.

\section{DAFTAR PUSTAKA}

Agustian, Ary Ginanjar. Rahasia Sukses Membangun Kecerdasan Emosi dan Spiritual. Jakarta: Arga, 2001.

Alister, McGrath, E. Christian Spirituality: An Introduction. Oxford: Blackwell Publishing, 2003.

Buttafuoco, Daniel P., Lima Alasan mengapa Alkitab adalah buku yang paling penting di dunia: Temukan kekuatan Firman Allah," disediakan di https://id.ptl.org/alive/why scripture. php diakses pada tanggal 2 November 2020

Chaplin, J.P. Kamus Lengkap Psikologi. Jakarta: Raja Grafindo Persada, 1999.

Dwiyanti, Ulfa. Skripsi: Pembentukan Kecerdasan Spiritual Melalui Kegiatan Ekstrakurikuler Keagamaan di SMK Negeri 4 Wajo Kab Wajo.” Makassar: UIN Makassar, 2018.

Fiah, Rifda El. "Mengembangkan Potensi Kecerdasan Spiritual Anak Usia Dini Implikasi Bimbingannya," KONSELI: Jurnal Bimbingan dan Konseling. Volume 01 No 2, 2014: 88.

Goleman, Daniel. Kecerdasan Emosional. Jakarta: Pustaka Gramedia Utama, 2007.

Hapsarini, Deslana R. \& Suprihati, Wahyu, "Peran Orang Tua Dalam Mengembangkan Kecerdasan Spiritual Anak Di Era Masa Kini," Veritas Lux Mea (Jurnal Teologi dan Pendidikan Kristen) Vol. 1, No. 2 (2019): 100-118

Hartono, Handreas, “Membentuk Karakter Kristen Pada Anak Keluarga Kristen,” Kurios: Jurnal Teologi dan Pendidikan Agama Kristen Vol 2, No 1 (2014)

Ho, Ro, Woo. Pembacaan Alkitab Secara Menyeluruh. Yogyakarta: Penerbit Andi, 2015.

Hotimah, Nur dan Yanto. "Peran Orang Tua Dalam Meningkatkan Kecerdasan Spiritual Anak Usia Dini, ” Indonesia Journal of Learning Education and Counseling; 2019.

Mau, Marthen, Implikasi Teologis Berita Pertobatan Yoel dalam Yoel 2:12-17; Magnum Opus: Jurnal Teologi dan Kepemimpinan Kristen, Vol 1, No 2 (Juni 2020):98-111.

Mau, Marthen. Integritas Guru Pendidikan Agama Kristen Dalam Membimbing Kepribadian Peserta Didik. Jakarta: PT Views, 2016.

Melly, Kartina, Manfaat dan Keuntungan Membaca Alkitab, disediakan di Copyright 2020 livingwatersweb.com All Rights Reserved diakses pada tanggal 2 November 2020

Mutak, A. Areng. The Importance of Spiritual Formation in Equipping Evangelical Seminary Students in Malang Region Indonesia. Ed.D. Dissertation. Asia Graduate School of Theology. Philippines, 2008.

Nurmala, Suciati, Hasyim, Adelina, dan Yanzi, Hermi, "Peranan Guru Terhadap Perubahan Sikap Sosial Siswa," Fakultas Keguruan dan Ilmu Pendidikan Universitas Lampung 2017:6

Penulis, Tim. Observasi terhadap Anak-anak Kristen. Pusat Damai: SMK Negeri 1 Parindu, 2019-2020. 
Sahartian, Santy. "Pemahaman Guru Pendidikan Agama Kristen Tentang II Timotius 3:10 Terhadap Peningkatan Kecerdasan Spiritual Anak Didik,” Jurnal Fidei, Vol.1, No. 2, 2018.

Selan, Yunus,. “Alkitab Di Dunia Postmodern,” Jurnal Luxnos Volume 5, Nomor 2, 2019.

Singgih, E. G. Apa Itu Teologi: Pengantar Ke dalam Ilmu Teologi. Jakarta; BPK Gunung Mulia, 2007.

Tokuan, Yuliana Margareta, Rivaie, Wanto, dan Imran, Artikel Penelitian: "Peran Guru Dalam Pembentukan Kepribadian Disiplin Siswa SMP Negeri 11 Kota Pontianak," Program Studi Pendidikan Sosiologi Jurusan Pendidikan Ilmu-Ilmu Sosial Fakultas Keguruan dan Ilmu Pendidikan Universitas Tanjungpura Pontianak 2015

Warren S. Benson dan Mark H. Senter III, Pedoman Lengkap untuk Pelayanan Kaum Muda 2. Bandung: YKH, 1999.

Yuliyatun. "Mengembangkan Kecerdasan Spiritual Anak Melalui Pendidikan Agama,” Jurnal Thulfula: Jurnal Inovasi Pendidika Guru Raudhatul Athfal. Volume 1, Nomor 1, JuliDesember, 2013.

Http://www.livingwatersweb.com/ manfaat-membaca-alkitab/ diakses pada tanggal 2 November 2020.

Https://personalitynabilah.wordpress. com/karakteristik-kecerdasan-spiritual/pada tanggal 2 November 2020.

Https://www.gkikayuputih.or.id/manfaat-membaca-alkitab/ diakses pada tanggal 2 November 2020.

Sanyospwt, "Manfaat Membaca Kitab Suci secara Teratur," pada 14 September 2018 disediakan di https://sanyospwt. com/2018/09/14/manfaat-membaca-kitab-suci secarateratur/ diakses pada tanggal 2 November 2020.

Filadelfia, Wawancara. Pusat Damai: SMK Negeri 1 Parindu pada bulan Agustus 2019.

Lambok, Wawancara. Pusat Damai: SMK Negeri 1 Parindu pada bulan September 2019.

Ogi, Wawancara. Pusat Damai: SMK Negeri 1 Parindu pada bulan Mei 2019.

Oktoviana, Wawancara. Pusat Damai: SMK Negeri 1 Parindu bulan Juli 2019.

Penulis, Observasi terhadap Anak-anak Kristen. Pusat Damai: SMK Negeri 1 Parindu pada bulan Maret 2019.

Samudera, Nika, Wawancara. Pusat Damai: SMK Negeri 1 Parindu pada bulan Juni 2019.

Yogi, Mikhael, Wawancara. Pusat Damai: SMK Negeri 1 Parindu pada bulan April 2019. 